\title{
HOLOCENE VARIATIONS IN THE SCOTTISH MARINE RADIOCARBON RESERVOIR EFFECT
}

\author{
Philippa L Ascough ${ }^{1,2,3} \bullet$ Gordon T Cook $^{2}$ • Andrew J Dugmore ${ }^{1}$ John Barber ${ }^{4}$ • Elaine Higney ${ }^{2} \bullet$ \\ E Marian Scott ${ }^{5}$
}

ABSTRACT. We assessed the evidence for variations in the marine radiocarbon reservoir effect (MRE) at coastal, archaeological Iron Age sites in north and west Scotland by comparing AMS measurements of paired marine and terrestrial materials (4 pairs per context). $\Delta \mathrm{R}$ values were calculated from measurements on material from 3 sites using 6 sets of samples, all of which were deposited around $2000 \mathrm{BP}$. The weighted mean of the $\Delta \mathrm{R}$ determinations was $-79 \pm 17{ }^{14} \mathrm{C} \mathrm{yr}$, which indicates a consistent, reduced offset between atmospheric and surface ocean ${ }^{14} \mathrm{C}$ specific activity for these sites during this period, relative to the present day $\left(\Delta \mathrm{R}=\sim 0{ }^{14} \mathrm{C}\right.$ yr $)$. We discuss the significance of this revised $\Delta \mathrm{R}$ correction by using the example of wheelhouse chronologies at Hornish Point and their development in relation to brochs. In addition, we assess the importance of using the concepts of MRE correction and $\Delta \mathrm{R}$ variations when constructing chronologies using ${ }^{14} \mathrm{C}$ measurements made on materials that contain marine-derived carbon.

\section{INTRODUCTION}

One of the most fundamental assumptions in radiocarbon dating theory is that there is global uniformity in the specific activity of ${ }^{14} \mathrm{C}$ in living organisms. The short residence time (1-2 decades) and rapid mixing of carbon in the atmosphere (Levin et al. 1980) mean that the assumption is valid for the well-mixed atmosphere and the terrestrial flora and fauna that atmospheric carbon supports, provided due corrections are made for the degree of isotopic fractionation that takes place during ${ }^{14} \mathrm{C}$ transfer through the food chain. Consequently, the record of atmospheric ${ }^{14} \mathrm{C}$ variations (from production rate changes and changes in the carbon cycle) may be measured directly through analysis of annually formed samples such as tree rings.

The residence time of carbon in the deep oceans is of the order of $1000 \mathrm{yr}$ (Sigman and Boyle 2000). This reflects the average length of time that a carbon atom remains in this reservoir before returning to the atmosphere by exchange. Therefore, the deep oceans are depleted in ${ }^{14} \mathrm{C}$ relative to the atmosphere because of the ${ }^{14} \mathrm{C}$ decay that occurs while the deep water is out of contact with the atmosphere. The surface oceans are intermediate in ${ }^{14} \mathrm{C}$ specific activity between the deep oceans and the atmosphere because this reservoir is a mixture of "new carbon" from the atmosphere via gaseous exchange and "old carbon" from the deep oceans.

This depletion of surface waters relative to the atmosphere would not be a major problem if the world's oceans were uniformly mixed, since a global age correction factor could be employed. However, circulation and mixing within the oceans are comparatively slow processes, leading to significant geographical and depth variations in the degree of ${ }^{14} \mathrm{C}$ depletion. These will depend upon factors such as the stratification of water masses, rates of current movement, the length of time that a body of water is in contact with the atmosphere, and the locations of water mass convergence and upwelling (Gordon and Harkness 1992).

\footnotetext{
${ }^{1}$ Institute of Geography, University of Edinburgh, Edinburgh EH8 9XP, United Kingdom.

${ }^{2}$ Scottish Universities Environmental Research Centre, Scottish Enterprise Technology Park, Rankine Avenue, East Kilbride, Glasgow G75 OQF, United Kingdom.

${ }^{3}$ Corresponding author: Email: pasc@geo.ed.ac.uk.

${ }^{4}$ AOC Archaeology Group, Edgefield Road, Loanhead EH20 9SY, United Kingdom.

${ }^{5}$ Department of Statistics, University of Glasgow, Glasgow G12 8QQ, United Kingdom.
}

(C) 2004 by the Arizona Board of Regents on behalf of the University of Arizona Proceedings of the 18th International Radiocarbon Conference, edited by N Beavan Athfield and R J Sparks RADIOCARBON, Vol 46, Nr 2, 2004, p 611-620 
Therefore, the reservoir age $\mathrm{R}(\mathrm{t})$, which is defined as the difference in conventional ${ }^{14} \mathrm{C}$ yr between samples grown contemporaneously in the terrestrial and surface marine reservoirs, varies spatially. $\mathrm{R}(\mathrm{t})$ will also vary temporally as a result of changes in reservoir size and input and output fluxes.

Estimates of temporal ${ }^{14} \mathrm{C}$ variations in the surface marine environment are based on models that employ the atmospheric ${ }^{14} \mathrm{C}$ data as input to produce a separate calibration curve for samples containing marine derived carbon (Stuiver and Braziunas 1993). Identification of spatially dependent ${ }^{14} \mathrm{C}$ variations have relied on studies performed in specific geographical areas (Stuiver et. al. 1986).

The aim of this research was to examine variations in the marine ${ }^{14} \mathrm{C}$ reservoir effect (MRE) in northeast Atlantic surface waters during the Scottish Iron Age (about 2000 BP). An accurate quantification of the MRE is crucial to constructing effective environmental chronologies when using material that incorporates ${ }^{14} \mathrm{C}$ from a marine source.

\section{Spatial Dimensions of $\triangle R / M R E s$}

The marine calibration curve provides an averaged correction for the MRE between the global surface oceans and the atmosphere through time. This correction value does not allow for geographic variations in the surface ocean ${ }^{14} \mathrm{C}$ content and the fact that local MREs may vary through time to significantly different extents from the global average (Stuiver and Braziunas 1993). Due to the short time interval required for tropospheric air masses to circulate globally (Levin et al. 1980), the atmospheric/terrestrial reservoir is relatively homogeneous with respect to ${ }^{14} \mathrm{C}$. However, the complex circulation patterns of the global ocean reservoir operate at much slower individual rates, producing a wide variation in the ${ }^{14} \mathrm{C}$ concentration of water masses at different depths and in different regions. The ${ }^{14} \mathrm{C}$ age offset of a local surface ocean area may, therefore, be significantly offset from the global marine calibration curve, depending upon local climate and oceanic variables. This positive or negative deviation in ${ }^{14} \mathrm{C}$ age is described as a $\Delta \mathrm{R}$ value. In areas where deep, ${ }^{14} \mathrm{C}$ depleted water is upwelled, the ${ }^{14} \mathrm{C}$ content of surface ocean water is reduced, and local MRE offsets increase, producing a positive $\Delta R$ value (Silar 1980; Goodfriend and Flessa 1997). Negative $\Delta R$ values (and therefore decreased local MRE offsets) are recorded where a strong inflow of water that is more thoroughly equilibrated with the contemporary atmosphere exists (Silar 1980). In addition to ocean circulation, climatic changes can heavily influence $\Delta \mathrm{R}$ values, these being primarily oceanatmosphere gas exchange rates and factors of wind speed, sea-ice cover, and temperature (Liss and Merlivat 1986; Broecker et. al. 1985; Stocker and Wright 1996; Barber et. al. 1999).

\section{Temporal Dimensions of MREs/ $\Delta R$}

$\Delta \mathrm{R}$ is usually assumed to be time independent in a given location. However, there is a growing body of evidence for large and rapid changes in MRE during known periods of extreme climatic change, including the transition from the last glacial maximum to the Bølling/Allerød $(\sim 13,000 \mathrm{BP})$ and between the Younger Dryas and the start of the Holocene warm period ( 10,000 BP). Such variations have been observed in the Atlantic Ocean using data from benthic corals (Adkins et al. 1998), planktonic foraminifera (Siani et al. 2001), and mollusc shells (Austin et al. 1995), and are identifiable over decadal to centennial timescales. These variations have been linked to changing ocean circulation patterns, especially to changes in ocean ventilation rates and in the age and depth of the source waters to various study sites. Investigation into whether MRE change is also visible over human timescales (i.e. the Holocene) is limited. Because climate changes on the scale of a glacial/ interglacial transition do not occur in the mid to late Holocene, we assume that identification of the correspondingly smaller $\Delta \mathrm{R}$ variations during this time would require a comprehensive and intensive sampling methodology, designed to pick up changes at a higher resolution. 


\section{METHODOLOGY}

Three main methods have been developed in response to the problem of quantifying reservoir ages and local $\Delta \mathrm{R}$ values. Firstly, it is often possible to obtain samples of marine organisms (generally marine mollusc shells) from an area where the pre-1950 calendar date (and location) of collection was recorded; museum archives often prove a useful source of this material (Mangerud and Gulliksen 1975). $\Delta \mathrm{R}$ is then calculated from the offset between the global marine model age at the time of collection and the measured ${ }^{14} \mathrm{C}$ content of the marine sample (Stuiver and Braziunas 1993; Dutta et al. 2001). However, since museum collections are confined to the recent past, any temporal study would be severely limited.

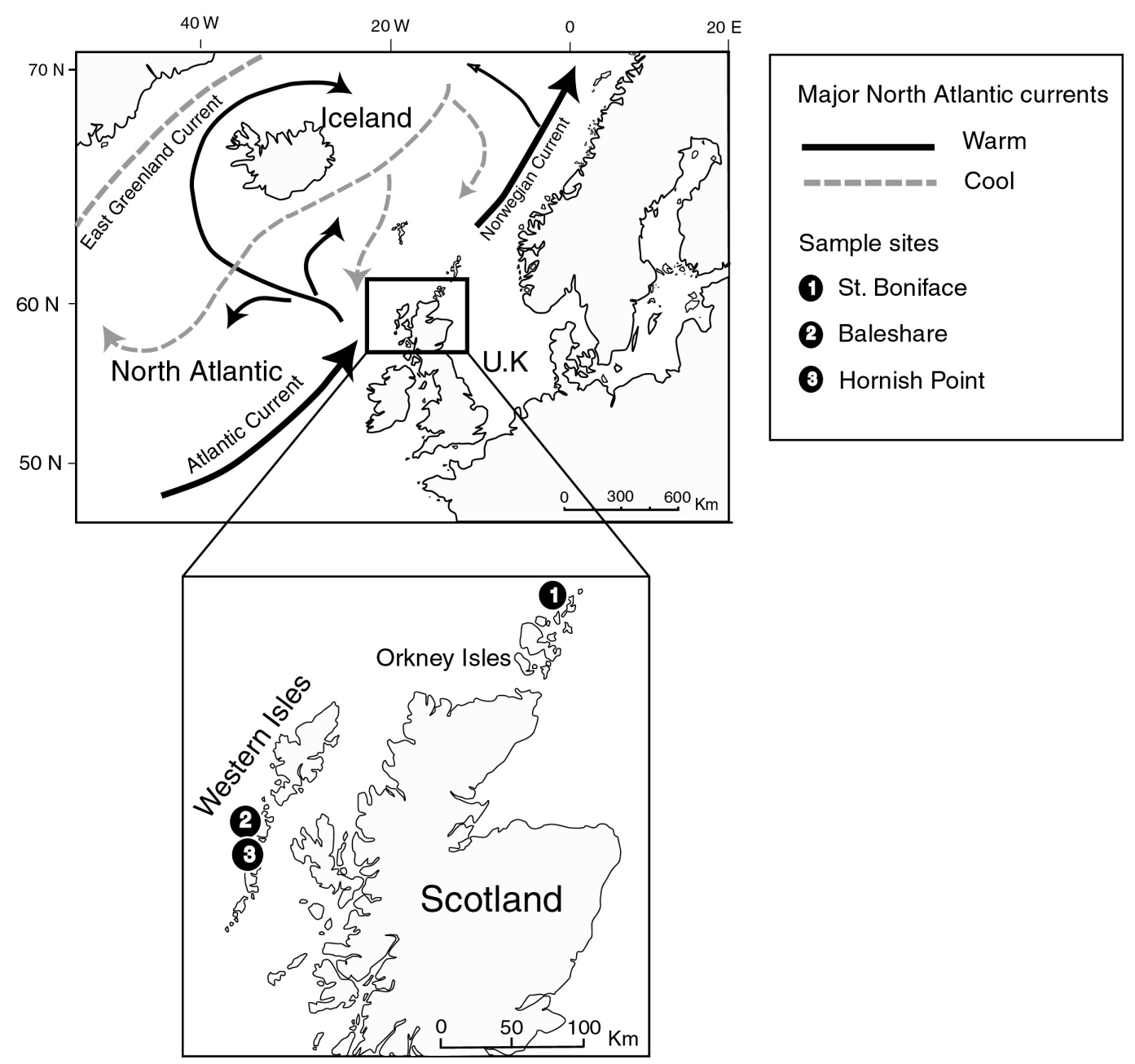

Figure 1 The study area showing investigated sites in Scotland: The study sites are coastal, bordering well-mixed oceanic waters. Major North Atlantic Ocean currents are shown, cold currents as grey, broken lines and warm currents as solid black lines. A well-developed northward flowing warm current (the North Atlantic Current) affects the Atlantic coast of Scotland, which tends to suppress MREs in the region. Climatic change can be expressed in a strengthening and weakening of the flow and related changes in $\Delta \mathrm{R}$. 
Secondly, the rapid and virtually instantaneous deposition of volcanic ash (tephra) in onshore and offshore deposits allows its use as a marker horizon. It is assumed that marine and terrestrial organisms in close association with the same tephra layer share an equivalent age of death, and the local $\mathrm{MRE}$ at the time of tephra deposition is calculated using the offset in their measured ${ }^{14} \mathrm{C}$ ages (Haflidason et al. 2000; Bondevik et al. 2001). Potential difficulties with this approach center upon varying sediment accumulation rates and sediment mixing prior to final incorporation into the deposit.

Finally, it is possible at many coastal archaeological sites to identify a deposit that contains domestic refuse including both marine and terrestrial material, which was gathered at the same time and is contemporaneous. ${ }^{14} \mathrm{C}$ age measurement made on the terrestrial material can be converted to a global model marine age, which can then be compared with the measured ${ }^{14} \mathrm{C}$ age of the marine material to determine $\Delta \mathrm{R}$ (Reimer et al. 2002).

The results we present here were obtained through a comparison of paired marine and terrestrial material from a range of Scottish archaeological sites (Figure 1). This methodology was selected as the most promising on the basis of a critical analysis of the advantages and limitations involved. The use of available known-age samples would have limited the possible spatial and temporal study parameters to previously collected material, restricting the opportunity to perform multiple or repeat measurements, a feature which we felt would be central to the accuracy of our calculated $\Delta \mathrm{R}$ values. The archaeological deposits we used each contained a large amount of suitable material, the nature of which allowed AMS measurement of single organisms. Suitable sampling sites were abundant in the study area, enabling us to apply strict selection criteria and discard-protocols for each individual deposit that was sampled. These were applied through close consultation with the excavators of each site and after examination of the excavation reports. At each site, an individual deposit or deposits were identified; where examination revealed a high likelihood that the deposit had not been disturbed since deposition and represented a period of rapid sediment accumulation, we extracted 4 samples of carbonized cereal grain and 4 samples of marine mollusc shell for AMS analysis (Figure 2).

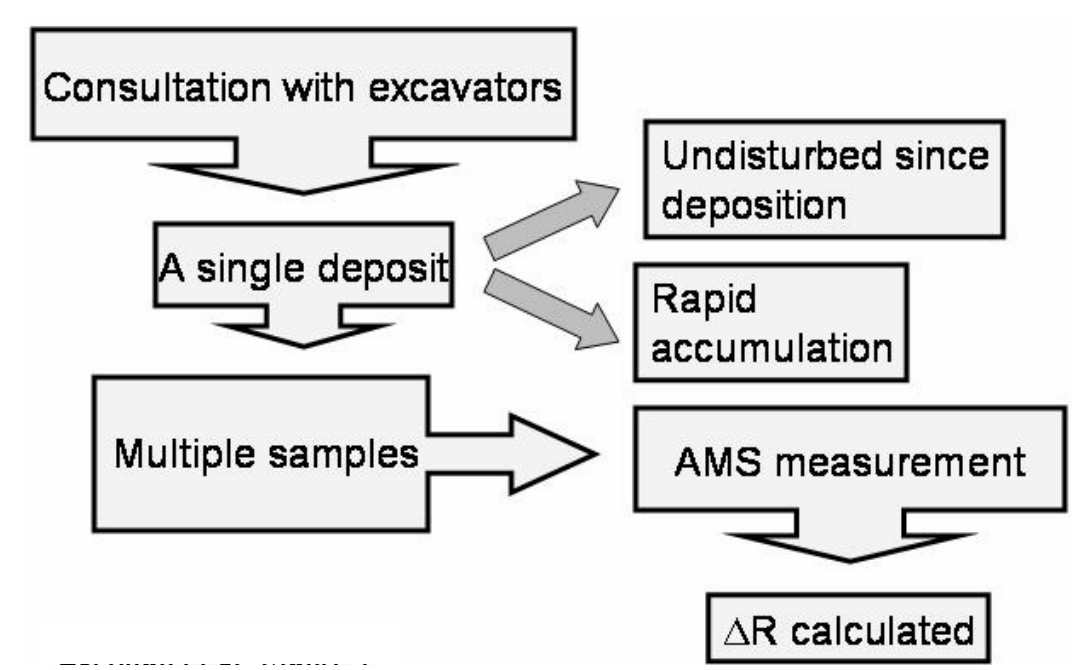

Figure 2 Outline of the paired sample methodology used in this study

To calculate $\Delta \mathrm{R}$ values, we used the method of Reimer et al. (2002). The maximum and minimum atmospheric ${ }^{14} \mathrm{C}$ ages for an individual deposit (derived from the weighted mean ${ }^{14} \mathrm{C}$ age of the grain 
samples) were used to calculate the modelled marine ${ }^{14} \mathrm{C}$ age range. The midpoint of the modelled marine ${ }^{14} \mathrm{C}$ age was then compared with the measured ${ }^{14} \mathrm{C}$ age of the marine shells to establish the size of the offset ( $\triangle \mathrm{R}$ value), from the global average, for this particular set of samples.

\section{RESULTS}

The $\Delta \mathrm{R}$ values were calculated using material around $2000 \mathrm{yr}$ old from 3 sites: Hornish Point and Baleshare on South Uist and St. Boniface on the Orkney Isles (Figure 1). Samples were taken from 3 separate deposits at Baleshare, two at St. Boniface, and one at Hornish Point, thereby allowing 6 assessments of $\Delta \mathrm{R}$ to be made. Within the group of $\Delta \mathrm{R}$ determinations, a low level of variation exists, all values being statistically the same at $95 \%$ confidence, on the basis of a $\chi^{2}$ test. This increases our confidence in the integrity of the determinations. The range of values is from -97 to -57 , with a weighted mean value for the whole group of -79 , and a standard deviation of $\pm 17{ }^{14} \mathrm{C}$ yr (Figure 3). This compares to commonly used values of $\Delta \mathrm{R}=\sim 0{ }^{14} \mathrm{C}$ yr for UK waters, e.g. $14 \pm 9{ }^{14} \mathrm{C}$ yr (Reimer et al. 2002), and a MRE [R(t)] for the region of $405{ }^{14} \mathrm{C}$ yr BP (Harkness 1983). The results from these sites, therefore, indicate a suppression of the MRE and, consequently, an elevation of the ${ }^{14} \mathrm{C}$ content in surface ocean waters around the sample sites at about $2000 \mathrm{BP}$.

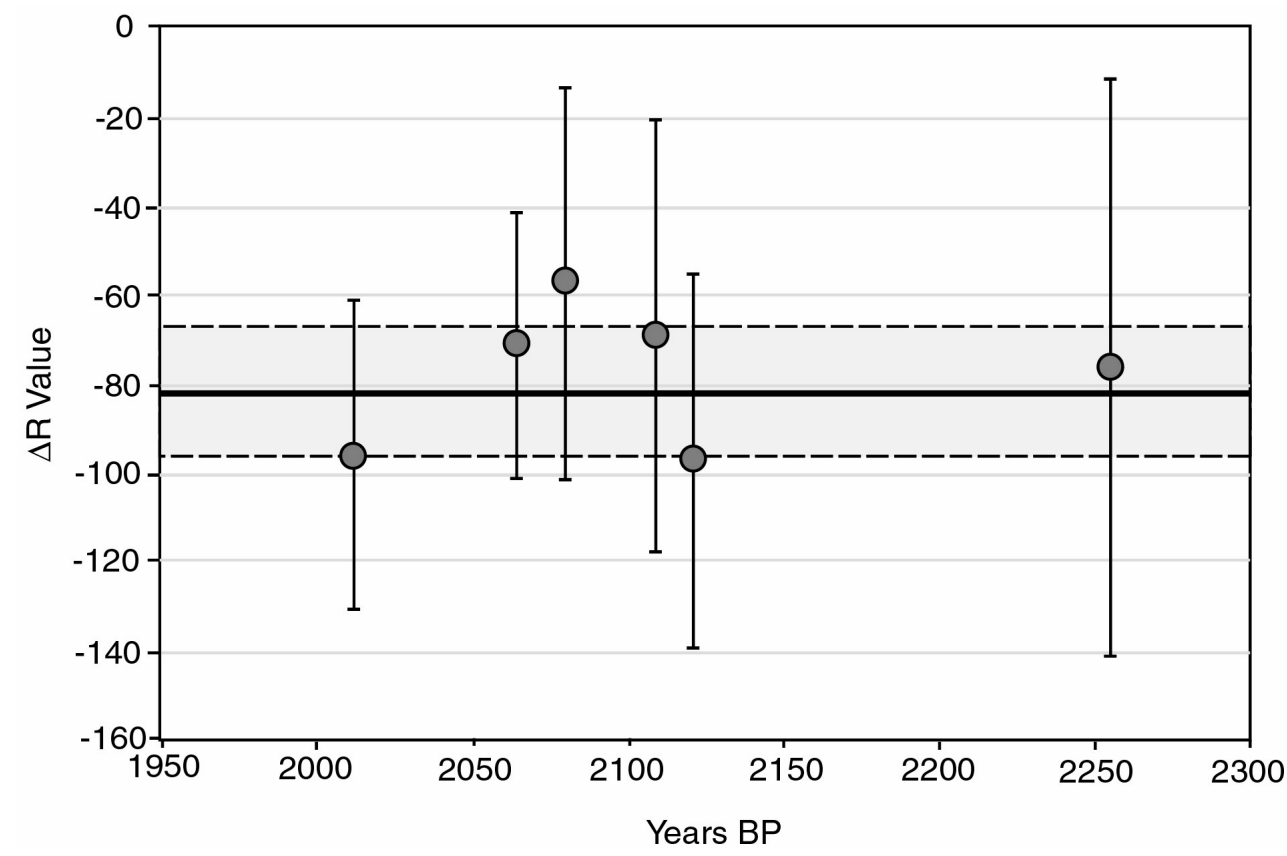

Figure $3 \Delta \mathrm{R}$ values from 6 deposits at Baleshare, Hornish Point, and St. Boniface, dated to about $2000 \mathrm{BP}$, showing the weighted mean $\Delta \mathrm{R}$ of $-79 \mathrm{yr}$ (solid back line) and standard deviation $\pm 17 \mathrm{yr}$ (shaded area) for the sample group. A $\Delta \mathrm{R}$ of $0 \mathrm{yr}$ is commonly applied to British waters.

\section{DISCUSSION}

\section{Chronological Implications of a Revised $\Delta R$ Value}

A revised $\Delta \mathrm{R}$ correction at $2000 \mathrm{BP}$ has significant implications for chronologies constructed using measurements of ${ }^{14} \mathrm{C}$ from marine organisms. These are widely used in Scotland to test theories of human-environment developments and interactions. Because activity periods at a single archaeolog- 
ical site are often separated by less than $100{ }^{14} \mathrm{C}$ yr, a 79 -yr marine correction would affect the perceived chronological relationship of material on an inter-site level. This has particular relevance where events at 1 site are placed into wider patterns of cultural and environmental change. Within a Scottish context, such changes are highly complex, as a wide range of physical landscapes exist within a relatively small land area. As specific developments are adapted to local conditions, to avoid looking at 1 site in isolation, a series of events must be placed upon an absolute timescale, and by linking these environmental and archaeological chronologies, a history of human-environment interactions can be established. The date of about 2000 BP lies within the Scottish Iron Age period, conventionally defined as lasting from about $800 \mathrm{BC}$ to about AD 800 (Armit and Ralston 2003), when environmental changes coincided with extensive cultural changes, including architectural developments. The timing of rapid transitions between several distinct building styles in different regions is currently far from clear, as is the extent to which a cultural change in settlement practice was a response to environmental variations. Two of the architectural styles in question are "brochs" and "wheelhouses." The term "broch" is traditionally used to define a group of prehistoric drystonebuilt roundhouses with a range of characteristic internal features, including hollow walls, intramural stairs, and galleries (Armit 2003). Some of them are tower-like and, for example, Mousa in Shetland is over $13 \mathrm{~m}$ high, but most are now ruinous and the tower-like structures may always have been exceptional (Fojut 1981). Wheelhouses, in contrast, are architecturally much less impressive. While they often enclose spaces that are as large as those found within brochs, they are often dug into the landscape, especially into sandy deposits and were visually unimpressive. Both site types had complex internal subdivision, usually radially arranged, and this became the dominant feature of the wheelhouse where radial dividing walls suggest the spokes of a wheel, giving rise to the site-type designation. The traditional interpretation is that the construction of wheelhouses post-dates that of the brochs; however, an accurate chronology of these architectural forms across the region is needed to determine whether the developments were part of an ordered sequence progression or a more complex regional pattern of co-existence. The impact of a $79-\mathrm{yr} \Delta \mathrm{R}$ correction to these questions may be illustrated using previously derived ${ }^{14} \mathrm{C}$ data from one of the study sites, Hornish Point (Barber 2003).

Human occupation at Hornish Point is estimated to span no more than $330{ }^{14} \mathrm{C}$ yr. The activity consists of a complicated and intensive series of building phases, where later structures often involved the use of material from earlier buildings and several wheelhouses were constructed, occupied, and abandoned over a short period. Ten previously derived radiometric ${ }^{14} \mathrm{C}$ measurements made on bulk samples of mollusc shells from these phases were calibrated using the marine INTCAL98 curve, first using a $\Delta \mathrm{R}$ of $0 \mathrm{yr}$, and then using the revised $\Delta \mathrm{R}$ of $-79 \pm 17{ }^{14} \mathrm{C}$ yr. The shift in calibrated age ranges of the measurements when the revised $\Delta \mathrm{R}$ is applied is shown in Figure 4. Because the majority of ${ }^{14} \mathrm{C}$ determinations at the site were made on marine mollusc shells, the assessment of the relative duration and age of phases on this individual site should not change radically through application of a revised $\Delta \mathrm{R}$ value. However, the position of various activity phases at Hornish Point on an absolute timescale, relative to that of many other sites (including broch and wheelhouse structures), is significantly altered.

\section{The Effective Application of MREs and $\Delta R$ Values to Chronological Constructions}

Our study highlights the importance of applying a correct $\Delta \mathrm{R}$ value when calibrating marine samples, particularly when the measurement results are to be compared with data from other sites. The use of AMS to analyze single entities with short life spans (e.g. single cereal grains and shells from marine organisms such as limpets, as presented here) has greatly increased our ability to determine accurate $\Delta \mathrm{R}$ values and has reduced much of the uncertainty previously associated with radiometric 


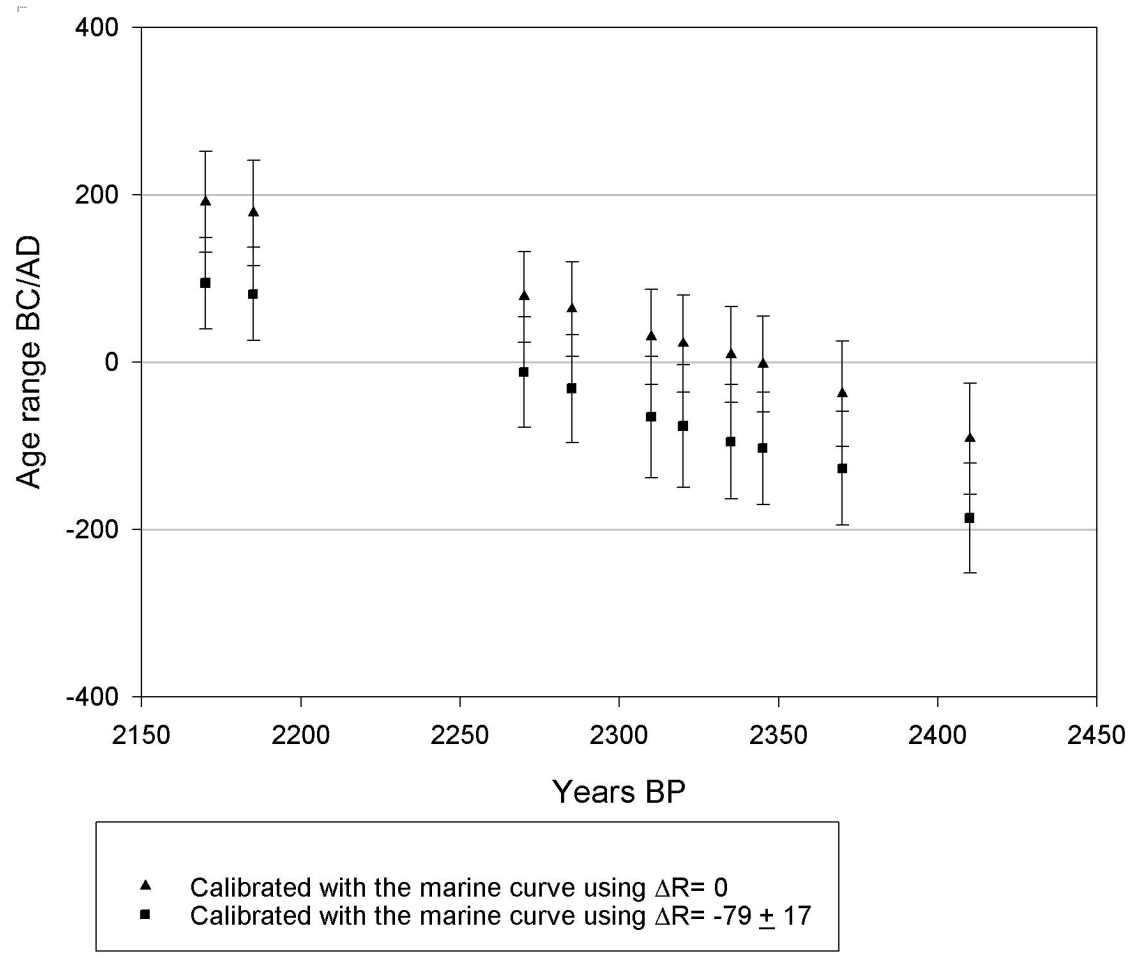

Figure 4 Comparison of the range of calibrated ages for 10 samples from the wheelhouse phases at Hornish point obtained using a $\Delta \mathrm{R}$ of $0 \mathrm{yr}$ (triangles) and a $\Delta \mathrm{R}$ of $-79 \pm 17 \mathrm{yr}$ (squares).

${ }^{14} \mathrm{C}$ dating of bulk samples. Radiometric analysis often involved the use of bulk charcoal samples and, therefore, the potential to introduce an "old wood" effect. In addition, individual contexts often contained insufficient material, which led to a potential compromising of results by bulking material from different contexts, accepting material from less than optimum contexts (e.g. contexts with signs of disturbance) and extrapolation of ${ }^{14} \mathrm{C}$ results between contexts (Barber 2003). All of these factors have affected previous interpretations. One example of this is an earlier assessment of the MRE at Hornish Point (Barber 2003). The methodology used involved a comparison of the ${ }^{14} \mathrm{C}$ age BP of 6 radiometric measurements on terrestrial material (either carbonized plant material or large animal bones) with equivalent marine shell samples. The sample pairs were obtained from both Hornish Point (2 samples) and the nearby site of Baleshare (4 samples). Due to the large volume of material required for each age measurement, it was only possible to obtain marine and terrestrial material from the same deposit in one instance, and other comparisons were made using samples from deposits that were in close proximity. In two instances, the terrestrial sample was composed of material from several adjacent deposits, again due to the sample masses required. In these cases, the equivalent shell age was calculated by interpolating between 2 measurements made on marine shells from deposits directly above and below the bulk of the terrestrial sample, assuming a known sedimentation rate for all deposits.

Using this methodology, the calculated differences between the marine and terrestrial ${ }^{14} \mathrm{C}$ ages of the 6 sample pairs ranged from +121 to $-405 \mathrm{yr}$. Using the Student's $t$ test, the differences, taken as a group, were not found to be significantly different from zero at $95 \%$ confidence. On the basis of these results, the authors elected to calibrate all ${ }^{14} \mathrm{C}$ measurements in the report using the standard 
atmospheric INTCAL98 curve, and consequently, the range of calibrated ages from the Hornish Point wheelhouse phases appear substantially older than those obtained using the marine calibration curve (Figure 5). These ages could imply that the wheelhouses were being constructed and used at the same time as some of the earliest brochs in Scotland. Determination of $\Delta \mathrm{R}$ using radiometric age measurements produces values between $-773 \pm 460$ and $-189 \pm 123$ due to a high likelihood that a range of entities of different ages were included in the measurement and a reduced likelihood of contemporaneous marine and terrestrial samples due to the restrictions imposed by the required sample masses discussed above. Through the use of AMS single entity dating, we were able to use sample material reliably of a single age and with a high likelihood that the marine and terrestrial material was contemporaneous. The revised data, re-calibrated with the marine curve and a $\Delta \mathrm{R}$ of $-79 \pm 17$, indicates that the Hornish Point wheelhouses were constructed during a later period. The revised $\Delta \mathrm{R}$ has important implications for our understanding of the nature of the relationship between both monument types when the ages are calibrated using the marine curve. The chronology of the wheelhouses at Hornish Point, based on a $\Delta \mathrm{R}$ of 0 , places these sites in a chronological span ranging from about $158 \mathrm{BC}$ to $\mathrm{AD} 252$ - at the extremes of the calibrated ranges. However, using the revised $\Delta \mathrm{R}$ of $-79 \pm 17$, this range is revised to $252 \mathrm{BC}$ to $\mathrm{AD} 149$. Traditionally, wheelhouses were viewed as humble successors that evolved, or perhaps, devolved from brochs at a time when the latter were effectively extinct, albeit that some brochs, especially those in the south of Scotland, persisted in use and indeed in construction into the 1st century AD. The Hornish Point dates imply that there is a significant overlap in construction dates of brochs and wheelhouses. This implies sophistication in the social landscape with impressive structures of several types being built, perhaps for personages of differing social grades or for other functions.

This re-interpretation of data from Hornish Point highlights the key issues inherent in applying different calibration methods to material from different locations, which is then fitted into one chronological framework.

\section{Environmental Mechanisms for $\Delta \mathbf{R}$ Variations}

The fact of variation in $\Delta \mathrm{R}$ demands some consideration of possible mechanisms for this change. A variety of climatic and oceanographic mechanisms could explain observed $\Delta \mathrm{R}$ variations through time. Paleoenvironmental data from the North Atlantic during the Holocene period indicates the potential for abrupt and intense oscillations in climate and oceanography, with both an overall longterm apparent cooling and evidence for the cyclicity of warming and cooling events (Bond et al. 1997). The key factor in MRE variation may prove to be ocean circulation patterns, as changes in the relative rate and size of flow of prevailing currents at different depths affect the concentration of ${ }^{14} \mathrm{C}$ in the local surface ocean water. On a Holocene timescale, these effects can be seen through evidence such as variation in ice-rafted debris inputs within North Atlantic Ocean sediments to the north of Scotland (Bianchi and McCave 1999).

\section{CONCLUSION}

The use of paired marine and terrestrial samples from onshore deposits is an effective way to quantify $\Delta \mathrm{R}$ values when used with strict controls and multiple analyses on single entities. If the sampling protocol does not ensure a high degree of accuracy, precision, and reproducibility within samples, then the relevance of the calculated $\Delta \mathrm{R}$ values is compromised. By using the methodology outlined here, the results we have obtained indicate observable deviation from a $\Delta R$ value of 0 at sites in the north and west of Scotland around 2000 BP. These results are important for both the calibration of samples containing marine carbon and construction of environmental and archaeological 


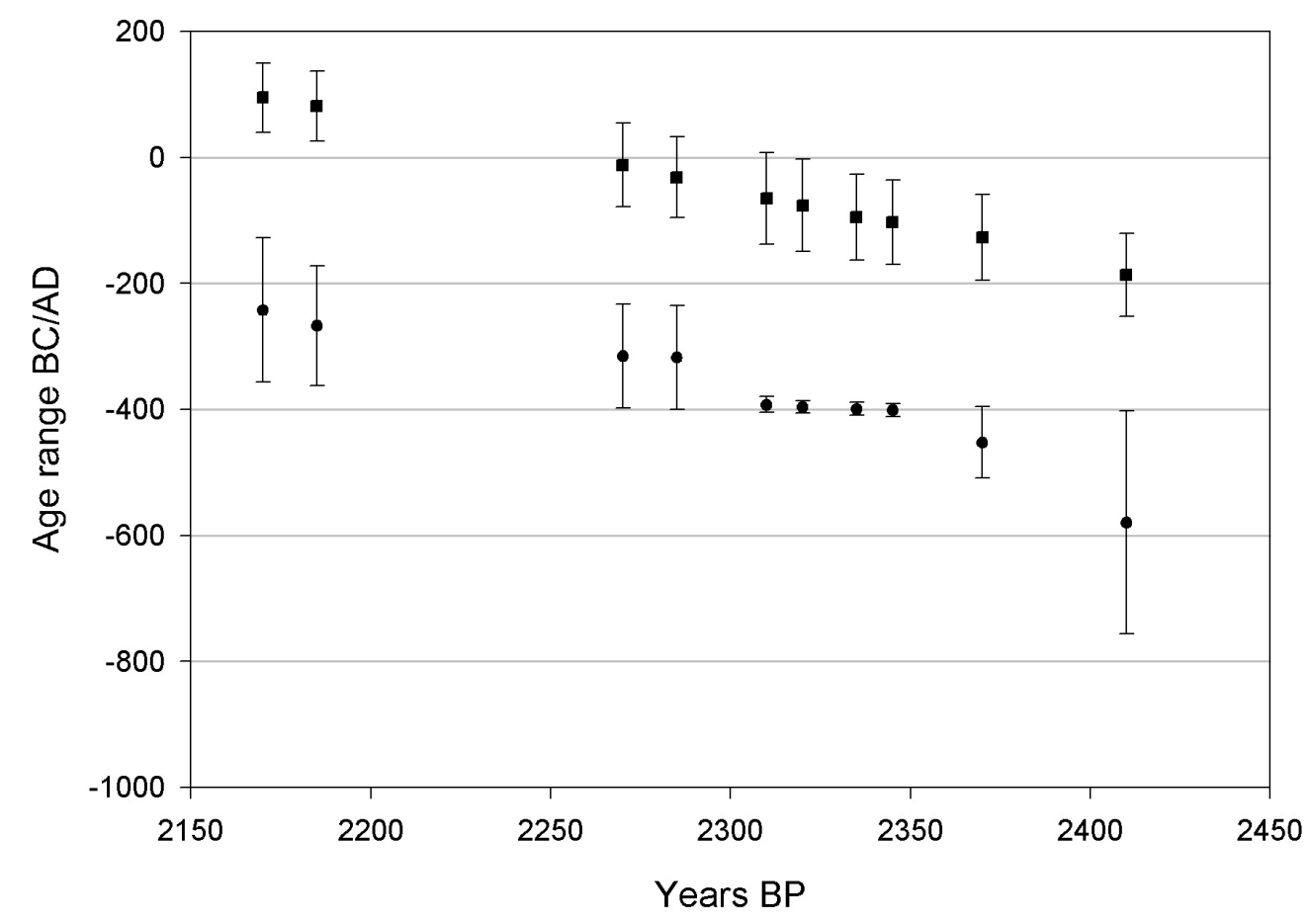

- Calibrated with the atmospheric curve

- Calibrated with the marine curve using $\Delta R=-79 \pm 17$

Figure 5 Comparison of the published age ranges for 10 samples from the wheelhouse phases at Hornish Point, where the INTCAL98 atmospheric calibration was applied (circles), with cal age ranges using the marine calibration curve and a $\Delta \mathrm{R}$ of $-79 \pm 17$ (squares).

chronologies, particularly where data from 1 site are used in relation to that of other sites, on an absolute timescale. It appears important to quantify an appropriate $\Delta \mathrm{R}$ correction for a given location and time period in situations where the accuracy and precision of measurements is crucial for interpretations. This is especially relevant when interpreting rapid changes over short timescales. Our work highlights the need for a wider understanding among users of current concepts of MREs and $\Delta \mathrm{R}$ values and how to use this information effectively when formulating interpretations based upon data from marine material. Finally, consideration should be given to the wider environmental mechanisms that underlie temporal variations in $\Delta \mathrm{R}$. It may be possible to link marine reservoir effects coherently to both regional paleocirculation changes, and also to local factors of circulation, climate, and coastal topography.

\section{ACKNOWLEDGEMENTS}

The authors gratefully acknowledge the support of Historic Scotland in funding this research. We also thank the researchers and excavators who kindly provided sample material for the ${ }^{14} \mathrm{C}$ measurements used to determine $\Delta \mathrm{R}$ values, Paula Reimer for the provision of data and Fortran coding that enabled us to calculate the $\Delta \mathrm{R}$ values, the staff of the University of Arizona and SUERC AMS Laboratories for ${ }^{14} \mathrm{C}$ measurements, and Patrick Ashmore (Historic Scotland) for many helpful discussions. 


\section{REFERENCES}

Adkins JF, Cheng H, Boyle EA, Druffel ERM, Lawrence Edwards R. 1998. Deep sea coral evidence for rapid change in ventilation of the deep North Atlantic 15,400 years ago. Science 280:725-8.

Armit I. 2003. Towers in the North; The Brochs of Scotland. Gloucestershire: Tempus Publishing.

Armit I, Ralston IBM. 2003. The Iron Age. In: Edwards $\mathrm{KJ}$, Ralston IBM. Scotland After the Ice Age: Environment, Archaeology and History 8000 BC-AD 1000. Edinburgh: Polygon. $184 \mathrm{p}$.

Austin WEN, Bard E, Hunt JB, Kroon D, Peacock JD. 1995. The ${ }^{14} \mathrm{C}$ age of the Icelandic Vedde ash; implications for younger Dryas marine reservoir age corrections. Radiocarbon 37(1):53-62.

Barber DC, Dyke A, Hillaire-Marcel C, Jennings AE, Andrews JT, Kerwin MW, Bilodeau G, McNeely R, Southon J, Morehead MD, Gagnon J-M. 1999. Forcing of the cold event of 8,200 years ago by catastrophic draining of Laurentide lakes. Nature 400: 344-8.

Barber J. 2003. Bronze Age farms and Iron Age farm mounds of the Outer Hebrides. Scottish Archaeological Internet Reports (SAIR) 3, The Society of Antiquaries of Scotland. URL: http://www.sair.org.uk/ sair3/index.htm. Last updated 13 May 2003. Accessed 6 October 2003.

Bianchi GG, McCave IN. 1999. Holocene periodicity in North Atlantic climate and deep ocean flow south of Iceland. Nature 397:515-7.

Bond G, Showers W, Cheseby M, Lotti R, Almasi P, deMenocal P, Priore P, Cullen H, Hajdas I, Bonani G. 1997. A pervasive millennial-scale cycle in North Atlantic Holocene and Glacial climates. Science 278: 1257-66.

Bondevik S, Mangerud J, Gulliksen S. 2001. The marine ${ }^{14} \mathrm{C}$ age of the Vedde ash bed along the west coast of Norway. Journal of Quaternary Science 16(1):3-7.

Broecker WS, Peng TH, Ostlund G, Stuiver M. (1985). The distribution of bomb radiocarbon in the ocean. Journal of Geophysical Research 90:6953-70.

Dutta K, Bhushan R, Somayajulu BLK. $2001 \Delta$ R correction values for the Northern Indian Ocean. Radiocarbon 43(2A):483-8.

Fojut N. 1981. Is Mousa a broch? Proceedings of the Society of Antiquaries of Scotland 111:220-8

Goodfriend GA, Flessa KW. 1997. Radiocarbon reser- voir ages in the Gulf of California: roles of upwelling and flow from the Colorado river. Radiocarbon 39(2): $139-48$.

Gordon JE, Harkness DD. 1992. Magnitude and geographic variation of the radiocarbon content in Antarctic marine life: implications for reservoir correction in radiocarbon dating. Quaternary Science Reviews 11: 697-708.

Haflidason H, Eiriksson J, Van Kreveld S. 2000. The tephrochronology of Iceland and the North Atlantic region during the middle and Late Quaternary: a review. Journal of Quaternary Science 15(1):3-22.

Levin I, Münnich KO, Weiss W. 1980. The effect of anthropogenic $\mathrm{CO}_{2}$ and ${ }^{14} \mathrm{C}$ sources on the distribution of ${ }^{14} \mathrm{C}$ in the atmosphere. Radiocarbon 22(2):379-91.

Liss PS, Merlivat L. 1986. Air-sea gas exchange rates: introduction and synthesis. In: Buat-Menard P, editor. The Role of Air-Sea Exchange in Geochemical Cycling. Dordrecht: D Reidel Publishing Co. p 11327.

Mangerud J, Gulliksen S. 1975. Apparent radiocarbon ages of recent marine shells from Norway, Spitsbergen and Arctic Canada. Quaternary Review 5:263-73.

Reimer PJ, McCormac FG, Moore J, McCormick F, Murray EV. 2002. Marine radiocarbon reservoir corrections for the mid- to late Holocene in the eastern subpolar North Atlantic. The Holocene 12(2):129-35.

Siani G, Paterne M, Michel E, Sulpizio R, Sbrana A, Arnold M, Haddad G. 2001. Mediterranean sea surface radiocarbon reservoir age changes since the last glacial maximum. Science 294:1917-20.

Sigman DM, Boyle EA. 2000. Glacial/interglacial variations in atmospheric carbon dioxide. Nature 407:85969

Silar J. 1980. Radiocarbon activity measurements of oolitic sediments from the Persian Gulf. Radiocarbon 22(3):655-61.

Stocker TF, Wright DG. 1996. Rapid changes in ocean circulation and atmospheric radiocarbon. Paleoceanography 11:773-96.

Stuiver M, Pearson GW, Braziunas T. 1986. Radiocarbon age calibration of marine samples back to $9000 \mathrm{cal} \mathrm{yr}$ BP. Radiocarbon 28(2B):980-1021.

Stuiver M, Braziunas TF. 1993. Modelling atmospheric ${ }^{14} \mathrm{C}$ influences and ${ }^{14} \mathrm{C}$ ages of marine samples to 10,000 BC. Radiocarbon 35(1):137-89. 